\title{
PENGARUH PROFITABILITAS DAN STRUKTUR AKTIVA TERHADAP KEPUTUSAN PENDANAAN PADA PERUSAHAAN MAKANAN DAN MINUMAN YANG LISTING DI BURSA EFEK INDONESIA PERIODE 2006-2008
}

\author{
Joana L. Saragih, SE, M.Si
}

\section{ABSTRACTION}

Joana L. Saragih, SE, M.Si, The purpose of research is to analyze the factors that total debt and equity of manufacturing company. There are two factors will be analyzed, they are profitability and assets structure. This research used 12 samples of manufacturing companies which listed in Indonesia Stock Exchange in 2006-2008. The secondary data that were contained in Indonesian Capital Market Directory were used as data sourse. The hypothesis was tested using multiple linear regression method and the data were processed using SPSS program. Result of this research shows that profitability and assets structure simultaneously significant influence to funding decision of total debt and equity of manufacturing companies. While partially, profitability negative significant influence to funding decision of total debt and equity, and assets structure positive significant influence to funding decision of total debt and equity. While simultan, profitability and assets structure significant influence to funding decision of total debt and equity. Assets structure influential dominance to funding decision of total debt and equity.

\section{PENDAHULUAN}

Keputusan penting yang dihadapi manajer keuangan dalam kaitannya dengan keberlangsungan operasi perusahaan adalah keputusan pendanaan atau keputusan atas struktur modal yang merupakan pilihan pendanaan antara hutang dan ekuitas. Manajer harus mampu menghimpun dana baik yang bersumber dari dalam maupun luar perusahaan secara efisien, yang berarti keputusan pendanaan tersebut merupakan keputusan yang mampu meminimalkan biaya modal yang harus ditanggung perusahaan. Biaya modal yang timbul dari keputusan pendanaan tersebut merupakan konsekuensi yang secara langsung timbul dari keputusan yang dilakukan manajer. Ketika manajer menggunakan utang, maka biaya modal yang timbul sebesar biaya bunga yang dibebankan oleh kreditur. Akan tetapi ketika manajer menggunakan dana internal, maka akan timbul biaya akibat menggunakan laba usaha (opportunity cost) dari dana internal yang dipergunakan.

Keputusan pendanaan merupakan cermin dari struktur modal, sehingga faktor-faktor yang mempengaruhi struktur modal dapat dipakai acuan dalam menentukan keputusan pendanaan dalam suatu perusahaan. Menurut Agus Sartono (2001:248), faktor-faktor yang mempengaruhi struktur modal adalah tingkat penjualan, struktur aktiva, tingkat pertumbuhan perusahaan, profitabilitas, variabel laba dan perlindungan pajak, skala perusahaan, serta kondisi intern perusahaan dan ekonomi makro.

Dari semua variable yang digunakanuntuk mengukur faktor-faktor yang mempengaruhi keputusan pendanaan, penulis menggunakan dua variabel bebas yaitu profitabilitas dan struktur aktiva.

Profitabilitas adalah kemampuan perusahaan memperoleh laba diukur dengan Return On Asset (ROA) yaitu jumlah laba bersih dibagi jumlah aktiva.

Struktur aktiva adalah proporsi investasi perusahaan dalam bentuk aktiva tetap. Struktur aktiva dalam pecking order theory memiliki hubungan yang positif dengan keputusan pendanaan. Frank dan Goyal (2005:7), menyatakan bahwa "relation between debt and 
tangibility of asset is reliably positive", yang artinya bahwa semakin besar aktiva tetap yang dimiliki perusahaan, maka peluang perusahaan untuk menggunakan utang semakin besar, karena aktiva tetap tersebut dapat digunak an sebagai jaminan bagi perusahaan yang hendak berhutang.

Tingkat Profitabilitas (ROA) masing-masing perusahaan makanan dan minuman tiap tahunnya pada periode 2006-2008 memiliki nilai yang berfluktuasi bahkan ada yang memiliki nilai negatif dikarenakan tingkat penjualan yang mengalami penurunan yang akan mempengaruhi tingkat laba perusahaan, sehingga kondisi ini menjadi begitu diperlukan suatu keputusan pendanaan yang tepat untuk memenuhi kebutuhan dana perusahaan agar profitabilitas tetap mengalami peningkatan tiap tahunnya, karena semakin tinggi profitabilitas suatu perusahaan maka menunjukkan semakin besar kemampuan perusahaan menggunakan sumber dananya yang berasal dari internal perusahaan yang berupa keuntungan dari operasi perusahaan.

Nilai struktur aktiva perusahaan mengalami perubahan setiap tahunnya yang terjadi karena proporsi antara aktiva tetap dengan total aktiva berubah ubah, sehingga diperlukan keputusan pendanaan yang tepat untuk memenuhi kebutuhan dana pada perusahaan. Semakin tinggi struktur aktiva suatu perusahaan semakin besar kemampuan perusahaan menggunakan sumber dananya yang berasal dari luar perusahaan.

Nilai keputusan pendanaan masing- masing perusahaan makanan dan minuman rata-rata mengalami peningkatan, kecuali Aqua Golden Mississippi Tbk yang mengalami penurunan sangat tajam. Penurunan ini karena laba yang diperoleh semakin meningkat, sehingga perusahaan lebih menggunakan dana internal daripada dana eksternal berupa utang, untuk melakukan pembiayaan terhadap operasional perusahaan. Perusahaan menggunakan hutang lebih besar dari modal sendiri. Demikian sebaliknya apabila perusahaan memiliki nilai DER lebih rendah dari 100 persen artinya perusahaan menggunakan hutang lebih kecil dari modal sendirinya. Adanya perbedaan debt to equity ratio (DER) yang ditunjukkan oleh masing-masing perusahaan menunjukkan bahwa setiap perusahaan mempunyai pertimbangan yang berbeda-beda dalam pengambilan suatu keputusan pendanaan yang tepat.

\section{Perumusan Masalah}

Dari uraian pendahuluan maka dapat dirumuskan permasalahan sebagai berikut :

1. Apakah profitabilitas dan struktur aktiva secara simultan berpengaruh signifikan terhadap keputusan pendanaan pada perusahaan makanan dan minuman yang listing Di Bursa Efek Indonesia Periode 2006-2008

2. Bagaimanakah pengaruh profitabilitas dan struktur aktiva secara parsial terhadap keputusan pendanaan pada perusahaan makanan dan minuman yang listing di Bursa Efek Indonesia periode 2006-2008?

3. Manakah yang mempunyai pengaruh dominan diantara profitabilitas dan struktur aktiva terhadap keputusan pendanaan pada perusahaan makanan dan minuman yang listing di Bursa Efek Indonesia periode 2006-2008?

\section{Perumusan Hipotesis}

Berdasarkan rumusan masalah, tujuan penelitian dan kajian teori yang relevan, maka hipotesis penelitian ini adalah:

1. Profitabilitas dan struktur aktiva secara simultan berpengaruh signifikan terhadap keputusan pendanaan pada perusahaan makanan dan minuman yang listing di BEI periode 2006-2008. 
2. Profitabilitas secara parsial berpengaruh negative dan signifikan terhadap keputusan pendanaan dan struktur aktiva secara parsial berpengaruh positif dan signifikan terhadap keputusan pendanaan pada perusahaan makanan dan minuman yang listing di BEI periode 2006-2008.

3. Struktur aktiva berpengaruh dominan terhadap keputusan pendanaan pada perusahaan makanan dan minuman yang listing di BEI periode 2006-2008.

\section{Tujuan Penelitian}

Adapun tujuan penelitian sebagai berikut:

1. Untuk mengetahui pengaruh profitabilitas dan struktur aktiva secara simultan terhadap keputusan pendanaan pada perusahaan makanan dan minuman yang listing di BEI periode 2006-2008.

2. Untuk mengetahui pengaruh profitabilitas dan struktur aktiva secara parsial terhadap keputusan pendanaan pada perusahaan makanan dan minuman yang listing di BEI periode 2006-2008.

3. Untuk mengetahui diantara profitabilitas dan struktur aktiva yang mempunyai pengaruh dominan terhadap keputusan pendanaan pada perusahaan makanan dan minuman yang listing di Bursa Efek Indonesia periode 2006-2008.

\section{Landasan Teori}

\section{Sumber-Sumber Pendanaan}

Menurut Bambang Riyanto (2002 : 209) ditinjau dari asalnya sumber modal (pendanaan) dapat dibedakan menjadi dua, yaitu:

1. Sumber Intern. Modal yang berasal dari sumber intern adalah modal atau dana yang dibentuk atau dihasilkan sendiri di dalam perusahaan seperti akumulasi penyusutan perusahaan yang berasal dari laba ditahan. i cadangan adalah kecil jumlahnya.

2. Sumber Ektern. Dana-dana yang sumbernya dari luar perusahaan adalah dana yang berasal dari para kreditur merupakan utang bagi perusahaan dan pemilik, peserta atau pengambil bagian dari perusahaan adalah dana yang akan tetap ditanamkan dalam perusahaan yang bersangkutan dan dana ini dalam perusahaan tersebut disebut modal sendiri

\section{Keputusan Pendanaan}

Keputusan pendanaan menurut Bambang Ryanto (2001:10) adalah keputusan yang berkaitan dengan penentuan sumber dana yang akan digunakan, penentuan perimbangan pembelanjaan yang terbaik atau penentuan sumber modal optimal. Fungsi pemenuhan dana atau fungsi pendanaan harus dilakukan secara efisien. Manager keuangan harus mengusahakan agar perusahaan dapat memperoleh dana yang diperlukan dengan biaya yang minimal dan syarat-syarat yang paling menguntungkan. Selain itu manajer keuangan juga harus mempertimbangkan dengan cermat sifat dan biaya dari masing-masing sumber dana yang akan dipilih karena masing-masing sumber dana memiliki konsekuensi finansial yang berbeda.

Keputusan pendanaan menyangkut beberapa hal antara lain Martono \& Agus Harjito (2004:5) : 1. Keputusan mengenai penetapan sumber dana yang diperlukan untuk membiayai investasi.

2. Penetapan tentang perimbangan pembelanjaan yang terbaik atau sering disebut struktur modal optimum.

Menurut Suad Husnan (2000:333), salah satu rasio yang dapat digunakan untuk mengukur proporsi hutang di dalam suatu perusahaan adalah debt to equity ratio (DER). Rasio ini 
menunjukkan beberapa bagian hutang yang dijamin oleh setiap rupiah modal sendiri. DER dapat dirumuskan sebagai berikut:

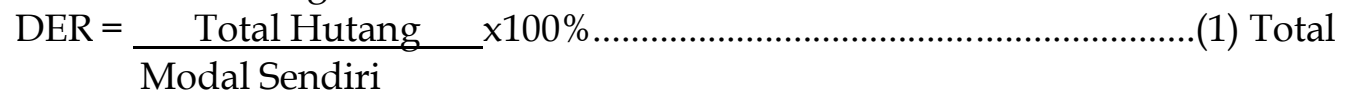

DER mencerminkan kemampuan perusahaan dalam memenuhi seluruh kewajibannya yang ditunjukkan oleh beberapa bagian modal sendiri yang digunakan untuk membayar hutang. Semakin besar penggunaan hutang maka semakin besar pula kewajiban yang harus dipenuhi perusahaan. Peningkatan hutang akan mempengaruhi besar kecilnya laba yang diperoleh perusahaan.

\section{Faktor-faktor yang mempengaruhi keputusan pendanaan}

Struktur modal merupakan bagian dari keputusan pendanaan sehingga faktor-faktor yang mempengaruhi struktur modal dapat dipakai sebagai acuan dalam menentukan keputusan pendanaan.

Menurut Agus Sartono (2001:248), faktor-faktor yang mempengaruhi struktur modal adalah:

1. Tingkat penjualan. Perusahaan dengan penjualan yang relatif stabil berarti memiliki aliran kas yang relatif stabil pula, sehingga perusahaan dapat menggunakan hutang dalam jumlah yang lebih besar dari pada perusahaan yang tidak stabil.

2. Struktur asset. Perusahaan yang memiliki struktur asset tetap dalam jumlah besar dapat menggunakan hutang dalam jumlah besar, hal ini disebabkan karena skalanya perusahaan besar mudah mendapatkan akses ke sumber dana dibandingkan dengan perusahaan kecil.

3. Tingkat pertumbuhan perusahaan. Semakin besar pertumbuhan perusahaan maka semakin besar kebutuhan dana untuk pembiayaan ekspansi. Semakin besar kebutuhan untuk pembiayaan mendatang maka semakin besar keinginan perusahaan untuk menahan laba.

4. Profitabilitas. Profitabilitas periode sebelumnya merupakan faktor penting dalam menentukan struktur modal. Dengan laba ditahan yang besar, perusahaan akan lebih senang menggunakan laba ditahan sebelum menggunakan hutang. Hal ini sesuai dengan pecking order theory yang menyarankan manager menggunakan pembiayaan yang pertama dari laba ditahan, kemudian hutang dan terakhir penjualan saham baru.

5. Variabel laba dan perlindungan pajak. Variabel ini sangat erat kaitannya dengan stabilitas penjualan jika variabilitas atau volatibilitas laba perusahaan kecil maka prusahaan mempunyai kemampuan yang lebih besar untuk menanggung beban tetap dari hutang. Adanya kecendrungan bahwa penggunaan hutang akan memberikan manfaat berupa perlindungan pajak.

6. Skala perusahaan. Perusahaan yang besar yang sudah well-estabilished akan lebih mudah memperoleh modal di pasar modal dibandingkan dengan perusahaan kecil, karena kemudian akses tersebut berarti perusahaan besar memiliki fleksibilitas yang besar pula.

7. Kondisi intern perusahaan dan ekonomi makro. Perusahaan perlu menanti saat yang tepat untuk menjual saham dan obligasi. Secara umum kondisi yang paling tepat untuk menjual obligasi atau saham adalah pada saat tingkat bunga pasar sedang rendah atau pasar sedang bullish. Tidak jarang perusahaan harus memberikan sinyal-sinyal dalam rangka memperkecil informasi yang tidak simetris agar pasar dapat menghargai perusahaan secara wajar.

\section{Pecking Order Theory}


Disebut peckin gorder theory karena menjelaskan mengapa perusahaan akan menentukan hierarki sumber dana yang paling disukai. Teori ini dikemukakan oleh Myers dan Majluf (1984) dalam Suad Husnan (2000:234).

Dalam pecking order theory dijelaskan hal-hal sebagai berikut:

1. Perusahaan menyukai internal financing (pendanaan dari hasil operasi perusahaan).

2. Perusahaan berusahan menyesuaikan rasio pembagian dividen yang ditargetkan dengan berusaha menghindari perubahan pembayaran dividen secara drastis.

3. Kebijakan dividen yang cenderung kaku disertai dengan fluktuasi profitabilitas dan kesempatan investasi yang tidak bisa diduga mengakibatkan bahwa hasil operasi kadangkadang melebihi kebutuhan dana untuk investasi meskipun pada kesempatan lain kurang. Apabila dana hasil operasi kurang dari kebutuhan investasi maka perusahaan akan mengurangi saldo kas atau menjual sekuritas yang dimiliki.

4. Apabila pendanaan dari luar (external financing) diperlukan, maka perusahaan akan menerbitkan sekuritas yang paling aman terlebih dahulu. Artinya dimulai dengan penerbitkan obligasi, kemudian diikuti oleh sekuritas yang berkarakteristik opsi (seperti obligasi konversi) dan akhirnya apabila masih belum mencukupi saham baru diterbitkan.

Menurut pecking order theory ini tidak ada struktur modal optimal yang diperoleh dari perimbangan hutang dan modal sendiri. Manajer cenderung menentukan keputusan pendanaan perusahaan berdasarkan hierarki sumber dana yang paling disukai yaitu mulai dari penggunaan sumber dana internal dan diikuti sumber dana eksternal yaitu hutang dan terakhir adalah menerbitkan saham.

Pecking order theory menjelaskan mengapa perusahaan-perusahaan yang profitabel umumnya meminjam dalam jumlah yang sedikit. Hal ini disebabkan karena perusahaan-perusahaan tersebut mampu menghasilkan kas internal yang memadai untuk keperluan investasinya, sehingga tidak ada penggunaan hutang lagi. Demikian juga sebaliknya perusahaan yang tidak profitabel akan cenderung menggunakan hutang yang lebih besar. Alasannya karena dana internal tidak mencukupi dan pembiayaan dengan hutang lebih disukai dibandingkan pembiayaan eksternal.

\section{Profitabilitas}

Profitabilitas menurut Sartono (2001:122) adalah kemampuan perusahaan memperoleh laba dalam hubungannya dengan penjualan, total aktiva mau pun modal sendiri. Ada beberapa cara mengukur profitabilitas yaitu Gross Profit Margin, Net Profit Margin, Return On Assets, Return On Equity, Profit Margin, Rentabilitas Ekonomis dan Earning Power. Dalam penelitian ini profitabilitas diukur dengan Return On Assets. Rasio yaitu membagi laba setelah pajak dengan total aktiva.

Dalam pecking order theory,penggunaan return on assets disebabkan karena ROA mencerminkan tingkat pengembalian (return) dari modal yang diinvestasikan perusahaan dalam keseluruhan aktiva. Semakin tinggi ROA maka kebutuhan dana dari extern semakin rendah karena laba yang dihasilkan semakin tinggi. Begitupun sebaliknya, semakin rendah ROA maka kebutuhan dana dari sumber extern akan semakin tinggi karena laba yang dihasilkan perusahaan rendah. Tinggi rendahnya tingkat pengembalian atau laba yang dihasilkan akan berpengaruh terhadap keputusan pendanaan perusahaan pada masa yang akan datang.

\section{Struktur Aktiva}

Struktur aktiva adalah proporsi investasi perusahaan dalam bentuk aktiva tetap. Menurut 
Munawir (2002:14) aktiva tetap adalah aktiva yang mempunyai umur kegunaan relatif permanen atau jangka panjang. Struktur aktiva dalam pecking order theory memiliki hubungan yang positif dengan keputusan pendanaan. Frank dan Goyal (2005:7) menyatakan bahwa relation between debt and tangibility of asset is reliably positive, yang artinya bahwa semakin besar aktiva tetap yang dimiliki perusahaan, maka peluang perusahaan untuk mendapatkan utang semakin besar, karena aktiva tetap dapat digunakan sebagai jaminan bagi perusahaan yang hendak berhutang. Struktur aktiva pada umumnya diukur oleh rasio perbandingan antara aktiva tetap dengan total aktiva.

Perusahaan yang memiliki aktiva tetap dalam jumlah besar, dapat menggunakan hutang dalam jumlah besar. Hal ini disebabkan karena besarnya aktiva tetap yang dapat digunakan sebagai jaminan atau kolateral hutang perusahaan Sartono (2001:248).

\section{METODE PENELITIAN}

\section{Populasi dan Sampel}

Populasi yang digunakan adalah perusahaan-perusahaan makanan dan minuman yang listing di Bursa Efek Indonesia periode tahun 2006-2008 yaitu sebanyak 14 perusahaan. Penentuan sampel ini dilakukan dengan cara purposive sampling yaitu teknik penentuan sampel dengan pertimbangan tertentu. Dari 14 perusahaan yang ada hanya 12 perusahaan yang digunakan sebagai sampel. Kriteria-kriteria yang digunakan sebagai pertimbangan dalam menentukan sampel adalah:

1. Perusahaan makanan dan minuman yang listing di Bursa Efek Indonesia periode tahun 20062008.

2. Perusahaan makanan dan minuman yang dalam laporan keuangannya tersedia data yang berhubungan dengan variabel yang diteliti.

\section{Operasionalisasi Variabel}

Operasionalisasi adalah batasan pokok permasalahan yang akan dibahas berdasarkan perumusan masalah. Variabel yang akan diteliti adalah :

1. Keputusan Pendanaan (Y). Keputusan pendanaan adalah tentang bentuk komposisi pendanaan yang akan dipergunakan oleh perusahaan. Pada penelitian ini, keputusan pendanaan diukur dengan menggunakan debt to equity ratio yang merupakan perbandingan total hutang dengan total modal sendiri pada perusahaan makanan dan minuman yang listing di Bursa Efek Indonesia periode 2006-2008. Satuan ukurannya adalah dengan persentase.

$$
\text { DER }=\frac{\text { Total Hutang } \quad \times 100 \%}{\text { Total Modal Sendiri }}
$$

2. Profitabilitas $\left(\mathrm{X}_{1}\right)$

Profitabilitas adalah kemampuan perusahaan untuk menghasilkan laba pada periode tertentu. Profitabilitas dihitung dengan menggunakan Return On Assets (ROA), yaitu membandingkan antara laba setelah pajak dengan total aktiva pada perusahaan makanan dan minuman yang listing di Bursa Efek Indonesia periode 2006-2008. Satuan ukurannya adalah persentase.

$$
\text { ROA }=\frac{\text { Laba Setelah Pajak } \quad \times 100 \%}{\text { Total Aktiva }}
$$

3. Struktur aktiva $\left(X_{3}\right)$

Struktur aktiva tetap, yang diukur dengan perbandingan aktiva tetap dan total aktiva pada perusahaan makanan dan minuman yang listing di Bursa efek Indonesia. Satuan 
ukurannya adalah persentase.

$$
\text { Struktur aktiva }=\frac{\text { Aktiva Tetap }}{\text { Total Aktiva }} \times 100 \%
$$

\section{Teknik Pegumpulan Data}

Teknik pengumpulan data dalam penelitian ini adalah dokumentasi, jadi data dikumpulkan dari buku-buku, karya ilmiah berupa skripsi dan ICMD (Indonesian Capital Market Directory).

\section{Teknik Analisis Data}

Teknik analisis data yang digunakan dalam penelitian ini adalah analisis regresi linier berganda yaitu :

$$
\begin{array}{ll}
\mathrm{Y}=\mathrm{a}+\beta_{1} \mathrm{X}_{1} & +\beta_{2} \mathrm{X}_{2}+\mathrm{e}_{\mathrm{i}} \\
\text { Dimana } \mathrm{Y} & =\text { Keputusan Pendanaan a } \\
& =\text { Konstanta } \\
\mathrm{X}_{1} & =\text { Profitabilitas } \\
\mathrm{X}_{2} & =\text { Struktur Aktiva } \\
\beta_{1}-\beta 3 & : \text { Koefisien Regresi } \\
\mathrm{e}_{\mathrm{i}} & : \text { Variabel pengganggu (risidual eror) }
\end{array}
$$

Analisis ini digunakan untuk mengetahui pengaruh variabel bebas terhadap variabel terikat. Dalam hal ini yang menjadi variabel bebas adalah profitabilitas dan struktur aktiva sedangkan variabel terikatnya adalah keputusan pendanaan.

\section{Hasil Penelitian}

\section{PEMBAHASAN HASIL PENELITIAN}

Hasil regresi linier berganda adalah:

$Y=36,090-2,460 X_{1}+1,952 X_{2}$, persamaan regresi linier berganda tersebut dapat diuraikan sebagai berikut:

$a=36,090$ memiliki arti jika profitabilitas $\left(X_{1}\right)$, struktur aktiva $\left(X_{2}\right)$ sama dengan nol, maka nilai keputusan pendanaan akan naik sebesar 36,090 satuan.

$\beta_{1}=-2,460$ memiliki arti bahwa setiap peningkatan profitabilitas $\left(X_{1}\right)$ sebesar 1 satuan, maka nilai keputusan pendanaan akan turun sebesar 2,460 satuan dengan asumsi variabel lainnya konstan.

B2 $=1,952$ memiliki arti bahwa setiap peningkatan struktur aktiva sebesar 1 satuan, maka keputusan pendanaan akan naik sebesar 1,952 satuan dengan asumsi variabel lainya konstan.

\section{Pembahasan Hasil Penelitian}

Persamaan regresi linier berganda menunjukkan arah dan besarnya pengaruh dari masingmasing variabel bebas terhadap variabel terikat. Pengaruh kedua variabel bebas terhadap keputusan pendanaan baik secara simultan maupun parsial dikemukakan sebagai berikut.

Nilai adjusted $R$ square dalam penelitian ini sebesar 0,319 artinya secara bersama-sama variabel profitabilitas dan struktur aktiva berpengaruh terhadap keputusan pendanaan sebesar 31,9 persen dan sisanya 68,1 persen dipengaruhi oleh variabel lain yang tidak d imasukkan dalam model. Hasil uji F menunjukkan bahwa profitabilitas dan struktur aktiva secara simultan berpengaruh signifikan terhadap keputusan pendanaan pada perusahaan makanan dan minuman yang listing di Bursa Efek Indonesia periode 2006-2008. Hal ini memiliki arti bahwa perusahaan memperhatikan kedua variabel bebas tersebut dalam menentukan 
keputusan pendanaan, terutama menyangkut penggunaan hutang sebagai sumber dananya. Semakin tinggi profitabilitas perusahaan, maka perusahaan bisa menggunakan dana sendiri untuk meningkatkan jumlah modal. Struktur aktiva yang tinggi akan memudahkan perusahaan memperoleh utang untuk modal usahanya.

Profitabilitas secara parsial memiliki pengaruh negatif dan secara statistik pengaruh tersebut signifikan terhadap keputusan pendanaan pada perusahaan makanan dan minuman yang listing di Bursa Efek Indonesia periode 2006-2008, yaitu dengan nilai kofisien sebesar $\quad$-2,067 dan nilai signifikansi 0,041. Pengaruh negatif dari profitabilitas terhadap keputusan pendanaan memiliki arti bahwa semakin tinggi profitabilitas yang dihasilkan perusahaan maka keputusan pendanaan perusahaan akan semakin rendah, karena dengan tingkat profitabilitas yang tinggi perusahaan mampu menyediakan dana internal dalam jumlah besar.

Struktur aktiva secara parsial berpengaruh positif signifikan terhadap keputusan pendanaan pada perusahaan makanan dan minuman yang listing di Bursa Efek Indonesia periode 2006-2008 yaitu dengan nilai koefisien sebesar 3,898 dan nilai signifikansi 0,000. Pengaruh positif dari struktur aktiva terhadap keputusan pendanaan memiliki arti bahwa semakin besar proporsi aktiva tetap yang dimiliki perusahaan maka semakin besar keputusan pendanaannya karena bertambahnya penggunaan hutang sebagai akibat kemudahaan memperoleh hutang. Hasil penelitian ini sesuai dengan pecking order theory, dimana semakin besar struktur aktiva yang dimiliki perusahaan, maka semakin besar juga peluang perusahaan menggunakan hutang. Hal ini disebabkan karena aktiva tetap yang dimiliki perusahaan dapat dijadikan jaminan untuk memperoleh hutang.

Struktur aktiva berpengaruh dominan terhadap keputusan pendanaan. Hal ini terlihat daristandardized coefficient Beta sebesar 0,306 ini berarti pertumbuhan aktiva berpengaruh dominan terhadap keputusan pendanaan sebesar 30,6 persen. Pengaruh dominan dikarenakan sektor makanan dan minuman merupakan produk yang memiliki batas kadaluarsa yang menentukan makanan dan minuman sudah tidak bisa dikonsumsi lagi, untuk itu perusahaan harus memproduksi untuk melakukan penjualan. Dalam melakukan produksi tentunya diperlukan sumber dana yang mencukupi, dengan struktur aktiva yang dimiliki perusahaan mampu memperoleh hutang untuk memperoleh sumber dana.

\section{SIMPULAN DAN SARAN}

\section{Simpulan}

1. Bedasarkan pengujian secara simultan diketahui bahwa variabel profitabilitas, dan struktur aktiva berpengaruh signifikan terhadap keputusan pendanaan pada perusahaan makanan dan minuman yang listing di Bursa Efek Indonesia periode 2006-2008.

2. Bedasarkan pengujian secara Secara Parsial

a. Profitabilitas berpengaruh negatif signifikan terhadap keputusan pendanaan pada perusahaan makanan dan minuman yang listing di Bursa Efek Indonesia periode 2006-2008. Memiliki arti bahwa semakin tinggi profitabilitas yang dihasilkan perusahaan maka keputusan pendanaan perusahaan akan semakin rendah, karena semakin tinggi laba yang diperoleh semakin kecil keinginan perusahaan untuk menggunakan hutang.

b. Struktur aktiva secara parsial berpengaruh positif signifikan terhadap keputusan pendanaan pada perusahaan makanan dan minuman yang listing di Bursa Efek Indonesia periode 2006-2008. Memiliki arti bahwa semakin besar proporsi aktiva tetap yang dimiliki perusahaan maka semakin besar keputusan pendanaannya karena aktiva 
tetap yang dimiliki perusahaan dapat dijadikan jaminan untuk memperoleh hutang.

3. Struktur aktiva berpengaruh dominan terhadap keputusan pendanaan pada perusahaan makanan dan minuman yang listing di Bursa Efek Indonesia periode 2006-2008.

\section{Saran}

1. Bagi Manajer Keuangan disarankan untuk memperhatikan profitabilitas dan struktur aktiva dalam menentukan keputusan pendanaan pada perusahaan Makanan dan Minuman yang listing di Bursa Efek Indonesia periode 2006-2008.

2. Bagi perusahaan sebaiknya memperhatikan variabel profitabilitas dan struktur aktiva untuk meningkatkan kinerja keuangan agar memiliki reputasi yang baik di mata kreditur. Perusahaan harus mampu melakukan efisiensi biaya, sehingga laba yang tersedia cukup untuk membayar bunga sebagai balas jasa atas dana yang dipinjamnya

3. Sampel hanyaperusahaan makanan dan minuman yang listing di Bursa Efek Indonesia periode 2006-2008 dan hanya menggunakan 2 variabel bebas, yaitu profitabilitas dan struktur aktiva. Penelitian selanjutnya disarankan untuk menambah jenis perusahaan yang dijadikan sampel dan memperpanjang periode waktu yang diteliti serta menambah jenis variabel bebasnya seperti tingkat penjualan, pertumbuhan perusahaan, skala perusahaan, dan kebijakan dividen, sehingga akan memeperjelas variabel-variabel yang akan mempengaruhi keputusan pendanaan perusahaan.

4. Bagi para investor disarankan sebelum menanamkam modal di perusahaan, perlu memperhatikan variabel profitabilitas dan struktur aktiva untuk mengukur kinerja perusahaan, agar investasi yang dilakukan memberikan tingkat keuntungan yang maksimal sesuai dengan yang diharapkan.

\section{DAFTAR PUSTAKA}

Brigham, Eugene.F and Joel F. Houston, 2001, Manajemen Keuangan, Edisis Kedelepan, Edisi Indonesia, Buku II, Penerbit Erlangga, Jakarta.

Bambang Riyanto, 2001, Dasar-dasar Pembelanjaan Perusahaan, BPFE, Yogyakarta

Husnan, Suad, 2000, Manajemen Keuangan Teori dan Penerapan Keputusan Jangka Panjang, Edisi 4, BPFE, Yogyakarka.

Ikatan Akuntan Indonesia, 2002, Standar Akuntansi Keuangan, Salemba Empat, Jakarta.

Indonesia Capital Market Directory, 2005, Institute for Economic and Financial Research, Jakarta.

Indriantoro, Nur dan Bambang Supomo, 2002, Metodologi Penelitian Bisinis Untuk Akuntansi dan Manajamen, Edisi Pertama, BPFE, Yogyakarta

Mason, Robert. D and Douglas A. Lind, 1999, Teknik Statistika untuk Bisnis dan Ekonomi, Edisi Kesembilan, Edisi Indonesia, Penerbit Erlangga, Jakarta.

Munawir, S. 2002. Analisis Laporan Keuangan, Edisi ke empat, Liberty.

Mayangsari, Sekar, 2001, Analisis Faktor-Faktor yang Mempengaruhi Keputusan Pendanaan Perusahaan: Pengujian Pecking Order Hypothesis, Media Riset Akuntansi Auditing dan Informasi, Vol. 1 No. 3 Desember 2001, Hal. 1-26.

Santoso, Singgih, 2003, SPSS Versi 10 Mengelolah Data Statistika Secara Profersional, PT. Elex Media Komputindo Gramedia, Jakarta. 